\title{
Power, Property Rights and the Issue of Land Reform: A General Case Illustrated with Reference to Bangladesh
}

\author{
MUSHTAQ HUSAIN KHAN
}

\begin{abstract}
The argument for land reform is most persuasive when the proposed land reform promises not only to improve distribution but also to increase growth and efficiency. Such is the promise in the GKI advocacy of radical redistributive land reform. In this paper, first (a) the Griffin, Khan and Ickowitz (GKI) and (b) World Bank positions on land reform are compared, and their points of agreement and disagreement identified. Secondly, the political economy of Bangladesh is examined to evaluate the appropriateness of these two competing neoclassical approaches for understanding the constraints in the agrarian sector. Thirdly, it is argued that the anomalous evidence on land transactions and productivity in Bangladesh cannot be easily accommodated within purely economic models of markets in the way that the neoclassical approach attempts. Paradoxically, both the World Bank's focus on institutional reform and GKI's focus on radical land reform are derived from such attempts and both suffer from similar empirical and theoretical problems. There is a strong case for going back to Brenner-type political economy approaches for understanding the dynamism and constraints facing agrarian transitions. Such an approach puts the analysis of class and power at the centre stage of an analysis of structure and change in the agrarian economy, and focuses on the distribution of power that prevents primitive accumulation in some countries leading to a capitalist transformation.
\end{abstract}

Keywords: Bangladesh, neoclassical approaches to land reform, intermediate classes, institutional reform, primitive accumulation

\section{INTRODUCTION}

The argument for land reform is most persuasive when the proposed reform promises not only to improve distribution but also to increase growth and efficiency.

Mushtaq Husain Khan, Department of Economics, School of Oriental and African Studies, University of London, Thornhaugh Street, Russell Square, London WC1H OXG, UK. e-mail: mk17@soas.ac.uk

I would like to thank Terry Byres and Henry Bernstein for commenting on an earlier draft, without implicating them in any errors that remain.

(c) Blackwell Publishing Ltd, Henry Bernstein and Terence J. Byres 2004. 


\section{Mushtaq Husain Khan}

In an idealized neoclassical world, the initial allocation of land would not matter because the market would work to re-allocate land to more efficient producers. Since the market clearly does not always work in this way, economists look for different types of market failures to identify the causes and effects of the inefficient allocation of land. Clearly, to be able to construct effective political and economic policy responses, we need to know (i) why and to what extent the existing allocation of property rights over land restricts net output and its growth below their potential, and (ii) the factors that prevent property rights from being re-allocated in efficiency and growth-enhancing directions. How effective are neoclassical responses to these questions?

In an important paper, Griffin et al. (2002) address both these questions within a broadly neoclassical framework to argue that redistributive land reform is necessary to accelerate agrarian growth in developing countries. This is an important argument because while it uses a neoclassical logic, it provides a critique of some aspects of the neoclassical approach that the World Bank and others use to argue against the necessity of land reform. In comparing their modified neoclassical argument with the mainstream ones, we will argue that the neoclassical tradition is particularly weak in its understanding and modelling of political power, and, as a result, the neoclassical identification of the sources of agrarian backwardness, even in the modified version, is deeply misleading.

Griffin et al.'s (2002) case for redistributive land reform appears to go against the mainstream view, represented for instance in World Bank documents such as Faruqee and Carey (1997) and World Bank (2000), that says that the focus of reform should be on improving property rights in developing country agriculture, strengthening institutions that reduce transaction costs, and then simply letting the market work to re-allocate land to more efficient users. On the face of it, the Griffin, Khan and Ickowitz (henceforth GKI) position appears to be much more radical: they argue for redistributive land reform as opposed to tenure reform or reforms addressing the stability of property rights or transaction costs in land markets. But while the two positions appear to be radically opposed, they have much in common. In particular, they share an underlying agreement that in developing countries small farms are more productive than large farms, i.e. they achieve higher yields per unit of land. They also agree that the re-allocation of land to small farmers does not come about because of different types of market failure. Their disagreement is really about the nature of this market failure, and how to correct it to bring about the desired redistribution of property rights.

Thus on the first of the two questions referred to above (does the current allocation of land keep output and growth below their potential?), both GKI and the World Bank agree that small farms are more productive and that a transfer of land from large to small farms would enhance both output and its distribution. However, they differ on how the yield difference between small and large farms is explained. While this does result in important differences in recommended policy initiatives, we will argue that ultimately the differences are superficial and the two approaches share some common underlying problems. 
GKI argue that the problem with large farms is that they enjoy a monopsony in the labour market, which means that a large farm is typically the only employer of labour in a locality. It follows that its employment decisions have a big effect on the going wage. If it employs more labour, wages go up, so it has an incentive to keep wages artificially low by under-employing labour. Low wages enable the large farm to maximize profits, but because it employs less labour than is economically efficient, output is lower than it might have been. This explains the lower yields (output per unit of land) on large farms.

In contrast, the World Bank does not use the market power of large farms and their desire to maintain profits by under-employing labour to explain their lower labour use. Instead, the Bank relies on more conventional labour supervision constraints to explain lower labour use on large farms. The argument here is that agriculture requires intensive supervision of labour. Small farms that are dependent to a greater extent on family labour (either as workers or supervisors) have an inherent supervision advantage over large farms that have to use hired labour. As a result, small farms can use labour more intensively than large farms, allowing them to achieve higher yields on land.

Both approaches agree that the efficient allocation of land would be to achieve a preponderance of small farms. In the GKI model this will break the monopsony power of large farms, allowing both wages and farm output to rise. In the conventional World Bank model, a preponderance of small farms will allow a more intensive supervision of labour, thereby allowing more labour to be used on each unit of land. Once again, output and yields will increase.

On the second question (why is it that the efficient allocation of land to smaller farms does not come about?) GKI and the World Bank appear to provide quite different answers. But in fact, GKI's claim that their model is a general one is logically flawed and an attempt to rescue it within the neoclassical framework makes it collapse into a special case of the World Bank position, while the latter under plausible conditions could equally result in policy conclusions identical to the GKI claim. More seriously, both positions share similar theoretical flaws and are inconsistent with important aspects of the empirical evidence.

GKI's model suggests that large landlords would not want to sell land even if they were actually using land less efficiently than small farmers. According to neoclassical economic theory, if small farmers can produce more output on each unit of land than large landlords, they should be able to buy out the latter at a mutually beneficial price. But GKI argue that large landlords make so much profit from their monopsony that they will not sell their land at any price that a small farmer can offer. It follows that compulsory redistribution is necessary to achieve the efficient re-allocation of land to small farmers.

The World Bank's answer is much more conventional. Small farmers would be willing to pay a higher price for land than the land is worth to the large farmer, and hence in a well-working market, land would be transferred to small farmers. The only problem is that property rights in land are not well defined, leading to large transaction costs in making effective transfers. This prevents sales of land from large farms to small farms. But if transaction costs could be 
lowered, small farms would acquire land, as large farms have no intrinsic reason to oppose land sales. Indeed they will benefit by selling land that they can use less productively than others. Hence land reform is not only disruptive: it is unnecessary.

But while these two arguments appear to be radically different, a closer examination shows that GKI's implicit claim that their model is a general one is inconsistent in terms of the neoclassical logic that they otherwise subscribe to. Small farmers should be able to offer a sufficient price to buy out inefficient large farmers even taking into account the monopsony profits of the latter, simply because efficient small peasant farmers will be producing even bigger surpluses according to GKI's own argument. If they are not offering these high prices, there must be high transaction costs somewhere that are preventing small farmers from making these bids. The difference between the GKI and World Bank positions then becomes a much less profound one that revolves around an assessment of the possibility of institutional reforms that can reduce specific transaction costs in specific contexts. If the transaction costs at issue can in fact be reduced, GKI's position collapses into the World Bank one since it must be better to achieve land redistribution without the disruption of compulsory transfers. And if the relevant transaction costs cannot be reduced, the World Bank's position would logically lead it to accept the role of some redistributive land reform in these cases.

Apart from questioning the apparent radicalism of the GKI model, we argue that a comparison of the GKI and World Bank approaches in the context of a contemporary developing country shows the weakness of the neoclassical framework in general for addressing questions of agrarian transition. Not only do we find the argument that small farmers in general are more productive unconvincing, looking for obstacles to enhancing agrarian productivity solely in terms of obstacles to the market logic is deeply misleading. We argue that a satisfactory answer to the question of why inefficient agrarian structures and institutions persist has to address issues of political economy, and in particular the distribution of class power that may be preventing institutional change in growth-enhancing directions.

As a model of blocked agrarian change (ignoring its flawed argument in favour of small farm efficiency), the GKI model at least makes an attempt to identify a possible source of political resistance to institutional change. The problem is that it tries to identify the source of this political resistance using an abstract and ahistorical neoclassical monopsony model, and the attempt ultimately fails. The framework proves to be logically flawed and collapses into a conventional transaction cost argument, which may support radical land reform but only in very special circumstances.

The standard transaction cost argument offered by the World Bank, however, is also not convincing because if lowering transaction costs is really to the benefit of all parties, why have the appropriate institutional changes to reduce transaction costs not already come about? Why do large and small farmers in developing countries have to await World Bank advice to realize that they will both gain by 
supporting reforms of land records or court systems that could reduce transaction costs? And even if they had not realized this in the past, why are these 'win-win' reforms not rapidly implemented when the World Bank comes along and proposes them, and even offers loans to have these reforms implemented? The neoclassical approaches are not asking or answering this obvious question. Clearly, some groups are opposed to these reforms, but who are they and why are they opposing them, and why is their opposition so successful in stopping reform?

Our examination of these contrasting neoclassical approaches serves to illustrate the stark limitations of an ahistorical approach to the problem of agrarian transformation. The conventional neoclassical approach ignores politics altogether; the GKI version tries to identify a political obstacle to change on the basis of an ahistorical model. In fact, the configuration of power in society is historically specific and can only be analysed in the context of specific cases. Yet this configuration of power is a critical variable determining the pace and direction of the agrarian transition that can in turn explain long-term productivity growth. We argue that identifying these specific configurations is much more important for explaining differences in agrarian performance across countries and over time, than static comparisons of yields on large and small farms and attempts to identify obstacles to market-based land transfers.

We will refer to data and evidence from Bangladesh as a specific example since all the authors we are discussing refer to this country. However, we believe that our methodological arguments are of general relevance. In contrast to both GKI and the World Bank, an examination of the political economy of Bangladesh suggests that the real constraint to productivity-enhancing changes comes from the distribution of power between factions engaged in primitive accumulation. This results in an effective stalemate in the distribution of land and a failure to achieve land consolidation in the hands of more productive classes. Primitive accumulation is the non-market re-allocation of land and is common in transition economies before capitalism has become dominant. By examining the evidence on the type of primitive accumulation taking place in Bangladesh, we can begin to identify the nature of the political problem facing any attempt to enhance agrarian productivity in this country. We examine the implications of factional competition, the role of the intermediate classes, and of political fragmentation and competition for processes of primitive accumulation in Bangladesh. These political problems explain why reforms to reduce transaction costs suggested by the World Bank have not been taken up within Bangladesh and why they are very unlikely to have any impact in the future. It is not surprising that in all historical cases of radical agrarian transformation, there have been parallel or prior changes in the distribution of political power that allowed these changes to be implemented. The real problem with the GKI and World Bank positions is that by failing to identify the real protagonists in possible future conflicts, these models are not even assisting the initiation of a political debate.

In the first of the following sections we will compare the GKI and World Bank positions, identifying their points of agreement and disagreement. In the 
second section, we will examine the political economy of Bangladesh to evaluate the appropriateness of these approaches for understanding the real constraints in the agrarian sector. In the third and final section we argue that the anomalous evidence on land transactions and productivity in Bangladesh cannot be easily accommodated within purely economic models of markets. This provides a strong case for going back to Brenner-type political economy approaches for understanding the dynamism and constraints facing agrarian transitions (Brenner 1976 1985; Byres 1996). Such an approach would put an analysis of class and power at the centre stage of an analysis of structure and change in the agrarian economy and would focus on how different types of primitive accumulation were helping or hindering a capitalist transformation of agriculture. This would in turn identify quite different problems and constraints facing productivity transformations in developing country agriculture.

\section{REDISTRIBUTIVE LAND REFORMS VERSUS INSTITUTIONAL REFORMS TO REDUCE TRANSACTION COSTS}

The model presented by GKI (2002) showing the necessity of land reform aims to explain a selection of key historical observations. They observe that redistributive land reform in South Korea and Taiwan, as well as the effective redistribution that happened in China in the 1980s, led to sustained agricultural growth in these countries. This claim is not necessarily historically correct, and is examined elsewhere in this special issue, by Bramall.

At the same time, GKI refer to examples of failed tenure reform in a number of countries, to show that institutional reforms that seek to strengthen or stabilize property rights have been much less successful. Leaving aside for the moment the question of how representative these examples are, GKI's motivation is to provide a model of the agrarian economy that shows two things: first, that a re-allocation of land to smaller farmers will result in increased output; and secondly, that this re-allocation will not happen through a market, however well defined property rights are, so that redistributive land reform is necessary.

While the differences between GKI and the World Bank are really on the second question, we need to say that their agreement on the first is based on a very partial reading of the cross-country evidence. Both GKI and the World Bank subscribe to the inverse size-productivity relationship in developing country agriculture that is based on widespread but controversial data from developing countries. The inverse size-productivity relationship argues that smaller farms have higher yields (or output per unit of land), and this in turn is explained by their more intensive use of labour and other inputs. The implication is that if large farms could be broken into a number of smaller ones, total agricultural output would increase. Neither GKI nor the World Bank argue that small farms are differently organized compared with large farms (and this is an important point for our subsequent discussion) but rather that they face different incentives. The inverse size-productivity relationship is given detailed critical scrutiny by Dyer in this special issue; and it is considered critically, later in this paper, with 
respect to Bangladesh. It is also considered in the papers by Byres, Sender and Johnston, and Bramall.

To explain the higher yields in small farms, GKI's starting point is the observation that in a labour-surplus economy, labour is implicitly cheap and so should be intensively used to maximize social output. Small farms use cheap family labour, or labour from the competitive (low-wage) market, and so they face a labour price that is close to the (low) social opportunity cost of labour. As a result, we expect small farms to use a lot of labour on each unit of land. In contrast, GKI argue that because large farms have a monopsony (there is a single employer in many areas) the employment decision of the single employer has an effect on the wage. As more labour is employed the wage goes up, reducing the profits on all previous employment. The profit-maximizing monopsonist thus employs less labour per unit of land than a farm in a competitive market, and, as a result, produces less output per unit of land. In a labour surplus economy, this amounts to inefficient resource use. This mechanism explains why smaller farms have higher yields.

The World Bank (2000, 33-4) position is very similar on the empirical sizeproductivity relationship, but they provide a somewhat different mechanism to explain the inverse relationship. In the World Bank view, based on mainstream neoclassical economic thinking, large farms employ less labour on each unit of land because developing country agriculture requires a lot of labour supervision and large farms have to spread scarce managerial capacities more thinly over a bigger area. When this happens there is no incentive to employ a lot of labour on each unit of land, because, after a point, additional labour cannot be induced to put in the appropriate effort given the shortage of trustworthy supervisors. In contrast, small farms have more family-based supervision capacities per unit of land, and so they can employ labour more intensively per unit of land. They may also be using more family labour as workers, and they may require less supervision since they each have a stake in the total output. The higher yields on small farms are then explained by the fact that they can use more labour per unit of land because they can supervise them more closely compared with large farms. The World Bank qualifies its position for countries like Bangladesh by pointing out that there are some very small micro-farms that are just not viable, and this is explained by their inability to access markets that can enable them to benefit from their supervision advantage. But leaving aside these very small microfarms, they subscribe to exactly the same inverse size-productivity relationship as GKI, expecting small farms to produce higher yields than large farms.

While the World Bank and GKI agree on the inverse size-productivity relationship, they disagree, apparently radically, on the second question, the policy required to achieve a greater preponderance of smaller farms. The World Bank supports the conventional neoclassical explanation of why land markets fail to re-allocate land to more efficient farmers, who in their argument happen to be small farmers. This explanation focuses on the excessively high transaction costs of buying and selling in the land market that can prevent more efficient farmers from buying up land from less efficient farmers. These include the costs of 
identifying whether titles are legal, transferring them safely and in a way that precludes future disputes with the seller or other claimants to the land, dealing with disputes and contests over the transfer, and so on, all of which can add up to a significant addition to the buying price or a significant deduction from the selling price. Since the land market would otherwise have enabled more efficient users of land to buy land from less efficient users at a mutually beneficial price, the implication is that if these costs of transacting can be reduced, the market alone will transfer land to more efficient farmers. Over time, the result would be a decline in the number of large farms and a proliferation of small farms. This conventional answer does not convince GKI because it does not explain why moves to strengthen agrarian property rights or tenancy rights in developing countries (at least in the examples they refer to) did not lead to the type of market-led land re-allocation to more efficient small farmers that the conventional model predicts. This leads GKI to look for reasons that can explain why large landlords have a systematic incentive not to allow market-led land reallocation, and therefore why redistributive land reform may be necessary to divest them of their surplus land.

The model GKI provide to explain the inverse size-productivity relationship appears also to provide an explanation of why market transfers of land will be resisted regardless of the transaction costs of market exchanges. We have seen that their explanation of the inverse size-productivity relationship assumes that large landlords enjoy a monopsonistic position in local labour markets. It is an empirical question as to whether large landlords do indeed have this kind of monopsonistic power in specific contexts. We will leave the empirical consideration of this question until later. The monopsony mechanism for explaining the inverse size-productivity relationship is of great importance for deriving their conclusion that redistributive land reform is necessary to achieve greater efficiency. It enables GKI to argue that the market will not result in a re-allocation of land to the more efficient small farmers, even if transaction costs could be lowered through property right reforms. This is because large landlords will stand to lose their monopsony position if they start selling land. Selling land increases the number of employers in an area, and competition between them drives up wages, reducing profits per unit of land for the large landlord deciding to sell land. The large landlord therefore refrains from selling land if the profit made by selling some of the land will not compensate for the lower profits on the rest of the land as a result of wages being bid up by new landholders.

However, this position is not sustainable in terms of a neoclassical logic in view of the developments in transaction cost economics following the work of Coase (1960), Demsetz (1980) and North (1990). The new transaction cost additions to the neoclassical logic show that, by definition, all market failures, including market failures of the monopsonistic type that GKI identify, must ultimately be due to some underlying transaction cost problem. When we examine GKI's model closely, we find that this must indeed be the case, though the transaction costs at issue may be quite specific. Furthermore, even in cases where specific transaction costs make it rational for landlords to resist selling, they may 
Figure 1 The monopsonistic labour market model

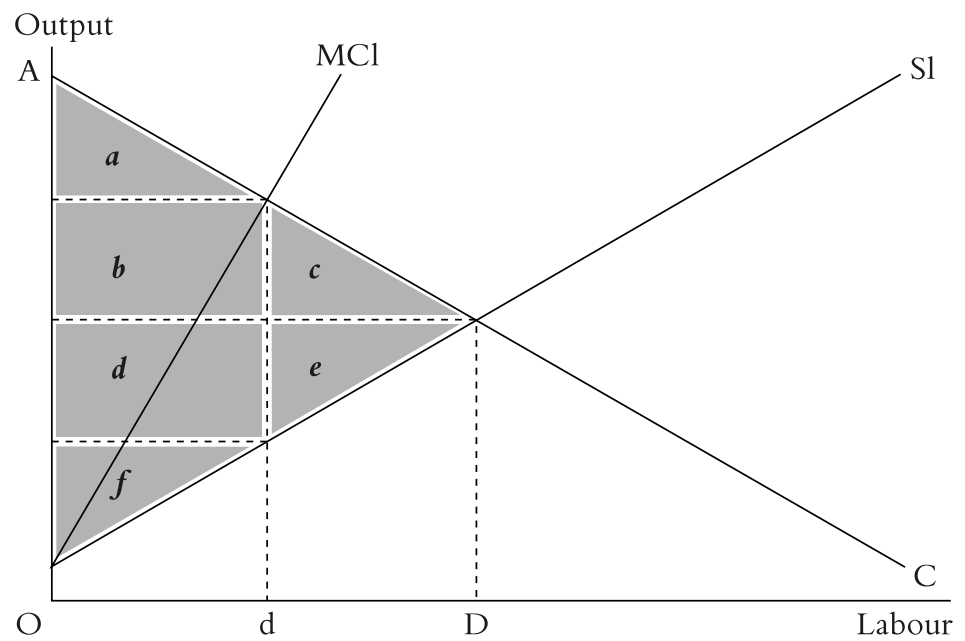

be unable to organize collective action to prevent land sales if there are a small number of landlords rather than a single landlord in the locality. We will briefly discuss the limitations of the GKI argument in terms of this neoclassical rationality before moving on to discuss the limitations of the neoclassical approach itself.

Figure 1 is based on Figure 1 in GKI (2002) and uses much the same notation. The diagram refers to an area owned by a single landlord enjoying a monopsonistic position in the labour market. AC is the derived demand for labour. Sl is the supply curve of labour and shows the market wage at each level of employment. $\mathrm{MCl}$ is the buyer marginal cost for the monopsonist. For each level of employment, the figure shows how much the last worker employed cost in terms of an addition to the total cost of the employer. The $\mathrm{MCl}$ curve is always higher than the Sl curve because the additional cost of hiring the last worker at a slightly higher wage is much higher than the wage itself, since all previously employed workers also have to be paid the higher wage. The profit-maximizing monopsonistic employer will only employ Od of labour, where the buyer marginal cost, $\mathrm{MCl}$ (the total additional cost of employing one more worker), equals the demand for labour, AC (the additional revenue generated by one more worker). In contrast, in a competitive labour market, no individual employer can keep wages down by his or her own employment decisions simply because a single employer employs too small a fraction of the total labour force. Uncoordinated employment decisions will then drive wages up to the point at which the labour supply curve, Sl, intersects with the labour demand curve, AC. Beyond that point, the revenue generated by additional workers will be lower than their wage and no further workers will be employed beyond OD. The collective profits of employers are now lower, and this can be seen visually in the diagram. The monopsonist's profit with employment at Od is $a+b+d$, compared with $a+b+c$, the collective profit at the competitive market-clearing level of employment 


\section{Mushtaq Husain Khan}

of OD. As long as $d>c$, the profit of the monopsonist is higher than the collective profit under competition. At the same time, the total output produced by the monopsonist is lower because of the lower labour use, by the amount $c+e$. Since we are looking at a fixed amount of land, the yield of land is also lower, since the same land now produces a lower output.

Not only is this allocation of land inefficient, GKI's mechanism appears to ensure that the market will not work to re-allocate land since the large landlord will not sell his land, given the profits he stands to lose if the labour market becomes (more) competitive. In particular, the large landlord will not sell if the price offered for any land sold does not compensate for the lower profits on the land that will be left as a result of higher wages. The easiest way to see this is to consider the extreme case where the monopsonistic landlord can sell all his land in a competitive land market. What price will persuade the landlord to sell? The standard answer is that the price has to be at least equal to the discounted net present value of the stream of profits. The monopsonist's stream of profits is $a+b+d$ in every period. However, the new landlords buying the land will by definition not be monopsonistic and they will collectively earn a stream of profits equal to $a+b+c$ in every period, and will therefore offer at most the discounted net present value of this stream. By definition, $d>c$, so the offer price cannot be high enough and no trade can take place. GKI's redistributive policy recommendation follows.

However, are GKI right to conclude that their result simply follows from the existence of a monopsony rather than some hidden high transaction costs? This implicit claim is important if their argument is not to collapse into a version of the standard policy conclusion of reducing transaction costs. According to the now standard neoclassical logic of transaction cost economics, in the absence of transaction costs, it should always be possible to buy out inefficient institutional arrangements. In other words, if a monopsony is inefficient, its survival must by definition depend on some hidden transaction costs. This follows from the way in which efficiency and market failure are defined in the neoclassical approach.

In the case we are looking at, there are individuals somewhere who are losing out from the loss of a social surplus of $c+d$ and, if they could be brought into the bidding, a price could be offered to the monopsonistic landlord that would induce a sale to the benefit of society. In a zero transaction cost world, many different coalitions could be formed to achieve this result. For instance, in the context that GKI describe, the buyers of land are not capitalist farmers but rather potential peasant owner-operators who are currently unemployed or employed at the artificially low wages set by the monopsonistic landlord. If potential peasant owner-operators who are currently excluded from the land market bid for the land, the price they would offer would be based on a much higher potential surplus that they could capture, equal to a stream of $a+b+c+d+e+f$ every period, since the opportunity cost of labour that they face is the true opportunity cost of family labour along the supply curve and everything on top of that is a surplus. The discounted net present value of this stream would clearly be sufficient to buy out the monopsonist and still leave the new peasant landowners better off. 
Even if we argue that some of these potential buyers may already be employed by the monopsonist (and so already receiving a part of the potential surplus equal to the amount $f$ ), the incremental surplus they could acquire every period by purchasing the land is at least $a+b+c+d+e$, and once again, a potential sale is possible since this is more than the monopsonist's income stream of $a+b+d$.

The idea that poor landless people could buy out large landlords appears to be unrealistic, but why is it unrealistic if it turns out they can generate more profit per unit of land than a large farmer? For a start, it could be that they find it difficult to raise the required sums in advance in financial markets. But this is a transaction cost problem based on the difficulty of poor people with little collateral credibly committing to repay debt. Not surprisingly, the World Bank and other agencies see the possibility of extending micro-credit type institutions to overcome this problem. Another problem may be that a large landlord may not be interested in selling minute pieces of land to each of a large number of small peasants. To make a bid, a number of small peasants would then have to get together and agree on a price. This too implies a transaction cost problem, this time in organizing a coalition to make a collective bid. These transaction costs are not conventional transaction costs of exchanging titles, but are transaction costs nevertheless. If GKI hold that the poor are more efficient users of land, then, according to the neoclassical logic, with good micro-credit institutions, good collective action on the part of the poor and an efficiently working land market, GKI's monopsonists would disappear.

Worse still, there is yet another logical problem with the GKI position. While it assumes high transaction costs for peasants bidding for land, it implicitly assumes zero-transaction costs for landlords colluding to prevent land sales. Even in very small, segmented rural labour markets, it is very unlikely that there will actually be just one employer of labour. Typically there would be a small number of dominant landlords. Would the monopsonistic outcome still hold? Possibly, but this outcome is now not very likely. Suppose there were just two landlords and they agreed to keep wages at a pre-determined low level by limiting employment. Unfortunately for the landlords, this agreement would not be a Nash equilibrium since both would have a strong incentive to break the deal. Taking the other's wage offer as given, each could greatly increase their employment and profits by offering a very slightly higher wage because this would attract all or most of the workers from the other landlord without significantly bidding up the wage. If either landlord believes that employment can be increased without significantly increasing wages, they would try to do this, as their profits would be greatly increased. Since the other landlord knows this too, that landlord too has an incentive to outbid for labour by just a little, and so on. The (Nash) equilibrium in this context is paradoxically the competitive wage and the two landlords unwittingly replicate the competitive outcome, much like the Bertrand outcome in a standard oligopoly.

In a repeated game, collusion could emerge provided the usual conditions held, in particular, if the number of colluding landlords was small and so the transaction cost of organizing the collusion was low. But even where successful, 


\section{Mushtaq Husain Khan}

such collusion would be under constant threat of breakdown, there would be ongoing transaction costs of maintaining the collusion, and we would expect to see continual attempts at reconstructing collusion with the attendant wage fluctuations. GKI do not provide any evidence of such attempts. The possibility of collusion breaking down is critical for their position, because without collusion there would be no incentive for large landlords to refrain from land sales. Indeed, there would be no social requirement for them to sell land in the first place, since employment would then be at or close to the efficient optimum anyway, even with a small number of dominant landlords.

The difference between the World Bank and GKI positions thus turns out to be far less radical than it appears at first sight. While the mechanisms explaining lower labour use on large farms is different, in both cases, the survival of inefficiency is ultimately due to different sets of transaction costs to do with operations in the land market. The apparent radicalism of GKI results from their failure to properly recognize the implications of the neoclassical approach that they adopt. On closer investigation, GKI's policy position is in fact identical to that of the World Bank. The Bank's policy position is to assist developing countries to clarify property rights and land records, reform legal systems, set up micro-credit systems and otherwise lower the transaction costs of land exchange, leaving the market to carry out the re-allocation of land to smaller farmers (Faruqee and Carey 1997; World Bank 2000). It should now be clear that GKI's explanation of persistent inefficiency in land structure is ultimately due to a very similar set of transaction costs, and at best if monopsony were a major problem, there would be some additional transaction costs to worry about. If they wish to argue that land reform is still necessary, they are essentially saying that the necessary reductions in transaction costs to enable small peasants to collectively bid for the land of larger landlords cannot be feasibly achieved. The disagreement, if any, is then about whether property rights, collective peasant organizations and other institutions can be improved sufficiently for the market to work to achieve an outcome that both positions agree is desirable. Even if the zero transaction cost neoclassical market is unattainable, the question from the neoclassical perspective is whether when we compare feasible land reform with feasible improvements in property rights and institutions, the latter might not offer a better route for improving labour employment from $\mathrm{Od}$ in Figure 1 to somewhere closer to OD.

\section{LAND RIGHTS AND AGRARIAN CONSTRAINTS IN BANGLADESH}

Thus the GKI model, despite its claims, turns out to be quite similar to that of the World Bank. This is not necessarily a problem, but, in fact, both GKI and the World Bank's models suffer from a number of closely related theoretical and empirical weaknesses. As a result, we argue that both are of limited relevance for addressing fundamental policy issues. We illustrate this with reference to Bangladesh, one of the countries to which GKI apply their model, and where the World Bank has applied its general policy position on institutional reforms. 
Table 1. Agricultural growth rates 1980-2000

\begin{tabular}{lcc}
\hline & $1980-90$ & $1990-2000$ \\
\hline Bangladesh & 2.7 & 2.9 \\
India & 3.1 & 3.0 \\
Pakistan & 4.3 & 4.4 \\
Low income average & 3.0 & 2.5 \\
\hline
\end{tabular}

Source: World Bank World Development Indicators (2002).

Over the last two decades, Bangladesh has achieved moderate rather than low growth in agriculture, if we can posit as moderate a rate comparable to the developing country average. This is shown in Table 1. Given some of the specific problems faced by agriculture in Bangladesh, this performance is not bad. These specific issues include the ecology of its floodplain agriculture that requires investment in both flood management and irrigation, and the high cost of flood management in the confluence of a powerful delta. But conversely, the land is highly fertile, with the prospect of significant improvements in yields if properly managed. The second specificity is a dramatic demographic transition that took the population from around 40 million in 1950 to around 130 million today. The reasons behind this demographic explosion are still not well understood, but it did result in a dramatic reduction in land-person ratios in agriculture.

Turning now to look at some of the data on land distribution in Bangladesh, we can see that despite GKI's claims, it does not fit the conditions required by the GKI model. Firstly, GKI's representation of the landholding structure in Bangladesh is very misleading. Instead of looking at the distribution of landholdings, GKI look at the Gini coefficient of land distribution. The latter takes into account all rural households, including the landless, to provide a single index of inequality in the ownership of land. Since this index shows a high degree of inequality in Bangladesh, GKI conclude that redistributive land reform is essential here. However, the Gini coefficient they report is high because of the large number of landless households in rural Bangladesh, and not just because land within landholdings is unequally distributed.

Table 2 provides data on actual landholdings, ignoring the functionally landless. We know that more than 50 per cent of rural households in Bangladesh are functionally landless (World Bank 2000, Table 1.15). The 2.1 million hectares of surplus land that GKI believe should be compulsorily redistributed would, if equally distributed to the roughly 10.5 million landless households, leave each of them with barely 0.5 acres per household. These are the smallest size of farms in Bangladesh, and, even according to the World Bank, these micro-farms are hardly viable. Ignoring the arithmetic viability of redistributive land reform in the context of Bangladeshi land-person ratios, we can ask if GKI's analysis nevertheless identifies the sources of agrarian backwardness. The two critical aspects of GKI's analysis are, firstly, that the monopsony position of large farms 
Table 2. The size distribution of land in Bangladesh 1984-97

\begin{tabular}{lccccccc}
\hline & \multicolumn{3}{c}{$1983-4$ Census } & & \multicolumn{3}{c}{$1996-7$ Census } \\
\cline { 2 - 4 } \cline { 7 - 8 } $\begin{array}{l}\text { Size of holding } \\
\text { (acres) }\end{array}$ & $\begin{array}{c}\text { Frequency } \\
(\%)\end{array}$ & $\begin{array}{c}\text { Owned } \\
\text { area (\%) }\end{array}$ & $\begin{array}{c}\text { Operated } \\
\text { area (\%) }\end{array}$ & $\begin{array}{c}\text { Frequency } \\
(\%)\end{array}$ & $\begin{array}{c}\text { Owned } \\
\text { area (\%) }\end{array}$ & $\begin{array}{c}\text { Operated } \\
\text { area (\%) }\end{array}$ \\
\hline Small (0.05-2.5) & 75.4 & 18.2 & 14.8 & & 83.1 & 26.2 & 23.3 \\
Medium (2.5-7.5) & 19.9 & 56.2 & 59.3 & & 14.3 & 56.3 & 59.4 \\
Large (7.5-) & 4.7 & 25.6 & 25.9 & & 2.6 & 17.5 & 17.3 \\
\hline
\end{tabular}

Source: World Bank (2000, Tables 1.5 and 1.6).

induces them to restrict labour employment to below the efficient level; and, secondly, that to preserve their monopsony position, they are unwilling to sell land to more efficient small farmers. Let us consider the credibility of these claims in the Bangladeshi context.

Table 2 shows that farms above 7.5 acres count as 'large farms' in Bangladesh. If there were any truly large farms likely to play a monopsony role in the labour market, they would be included in this category. But we see that all farms above 7.5 acres together controlled only 26 per cent of operated area in 1984, and this shrank to 17 per cent in 1997. Even so, some of these farms might still have played a monopsony role if they were the dominant employers of rural labour, and if they could successfully collude. But if employers in other size categories are significant employers of labour and if they have no incentive to restrict employment, even the collusion of the large farmers will not have a significant effect on wages. We know that, with some regional variation, 'small' and particularly 'medium' farmers are significant employers of labour in the rural labour market in Bangladesh. Even the smallest farms were found by Ahmed (1981) to depend on hired labour for as much as 50 per cent of their labour requirements. Indeed Boyce (1987, 203-6) uses census data from 1976/7 to show that smaller farms monotonically use more hired labour per acre than larger farms. Note, of course, that the hiring of labour does not mean that small farms are 'capitalist' since even petty commodity producers need to employ labour during peak periods. But if large farms account for only about a fifth of total acreage, and they also employ less hired labour per acre than small and medium farms, they can only be employing well under a fifth of total farm labour. It must be the case, therefore, that regardless of attempts at collusion, the employers of labour are too numerous for 'large' landlords to attempt to play a monopsonistic role in the labour market in Bangladesh and countries like it.

As to whether large landlords try to prevent land sales, there is no evidence that this is the case. Bangladeshi economists studying the land market have never raised this as an issue, but they have identified a very different analytical question. Despite the Bangladeshi land market being very active, there is no systematic evidence over time of land getting concentrated in any particular size 
category (van Schendel 1982; Bhaduri et al. 1986; Mahbub Ullah 1996; Rahman 1986, 1988; Pandian 1987; M.M. Khan 1987; Feldman and McCarthy 1987). This observation provoked an extensive debate on the data and the trends expected in land concentration in a market economy such as Bangladesh. The debate exposed many problems of measurement and methodology and resulted in an academic consensus that the tendency towards the concentration of land in any particular 'efficient' size-category faced powerful counter-tendencies since net concentration was happening very slowly if at all. Data that are more recent throw further doubt on the possibility that land concentration is increasing or even being maintained through the land market. If the land market was maintaining or increasing land concentration, the 'large' or at least the 'medium' group should account for a bigger share of total land over time. But as Table 2 shows, if there is any trend at all in recent years, it is that the share of land held by the smallest size group is increasing.

One interpretation of the growing share of land going to small farmers is that 'small' farmers are the most efficient group, and they are succeeding in buying land. This would be the most desirable outcome from the point of view of the neoclassical analysis of economic efficiency, but it would directly contradict the GKI hypothesis that monopsony power was preventing land transfers to more efficient small farmers. However, from the gap between owned and operated areas shown in Table 2, we see that the 'medium' farm group was leasing in from the 'small' group a net area in the region of 3 per cent of the total every year. This suggests that some farms at least within the 'medium' group were more efficient than others within the 'small' group, or that the minimum efficient scale of farming was larger than the land that many small farmers owned. The World Bank's statistical analysis also suggests to them that in fact it is the size class classified as 'medium' that is the most efficient in Bangladesh in terms of agricultural productivity (2000, 33-4). But if medium farmers are more efficient, as the leasing data and World Bank evidence suggest, and yet land is getting more fragmented, then the evidence points to problems in the land market that are quite different from those suggested by GKI. These problems could include demographic and other pressures leading to land fragmentation, and problems in the market in land preventing efficient farmers (who could well be medium or large farmers) from purchasing land fast enough to reverse this tendency. If this is our assessment, then the increasing fragmentation of land is a cause for worry rather than an indication of a well-working land market.

Aggregate figures for the land-person ratio over time show the importance of demographic pressures in Bangladesh. The ratio of cultivable land to rural population declined from 0.276 acres per person in agriculture in 1987 to 0.229 acres in 1995, a decline of 17.2 per cent in less than a decade (World Bank 2000, Table 1.4). This demographic pressure, together with inheritance laws that divide land equally amongst all brothers and in theory (and sometimes in practice) provides a share to sisters as well, provides a powerful tendency in the direction of land fragmentation. This could either augment market forces in the same direction (towards smaller farms) or provide a countervailing force against 
market tendencies favouring greater concentration. In either case, demographic forces have to be part of any explanation of the growing fragmentation of land. But our interpretation of the economic effects of fragmentation will depend on whether we believe demography augments or counters moves in the direction of economic efficiency. If demographic forces are running counter to economic efficiency, then far from the distribution of land being too concentrated, the problem in countries like Bangladesh may be an excessive fragmentation of land brought about by non-economic pressures, which the land market is failing to undo fast enough.

To make any further progress we have to return to a more fundamental question on which GKI and the World Bank agree, but which is in fact a contentious starting point. Who are the efficient farmers in Bangladesh? Does it have anything to do with the size of farm? The inverse size-productivity relationship that GKI and the World Bank subscribe to is to some extent supported by older work, usually based on the aggregate agricultural census data of the Bangladesh Bureau of Statistics. For instance, Boyce (1987, Tables 7.1 and 7.2) using census data for 1976/7 finds an inverse relationship not only between farm size and labour use but also between farm size and fertilizer use, irrigation and cropping intensity. While generally supporting the inverse size-productivity relationship, Boyce points out that some of the correlations are in fact misleading and could have been picking up spurious factors. For instance, the relationship between farm size and fertilizer use could be due to the fact that districts with high fertilizer use also happened to have smaller farm sizes. Disaggregating to the district level shows that while the negative relationship persists in some districts, there are just as many districts with a positive relationship, i.e. where larger farms use fertilizer more intensively (Boyce 1987, 209). Similarly, Boyce points out that the negative relationship between farm size and percentage of area irrigated only holds for labour-intensive irrigation. When disaggregated to modern irrigation like lift pumps and tubewells, the relationship is much weaker and is overturned in many districts, giving a positive size-productivity relationship (Boyce 1987, 207-9). In other words, when we look at mechanical and capital-intensive irrigation, large farms often do better, a conclusion that can be hardly surprising. Finally, the inverse relationship between farm size and cropping intensity can be largely explained by the fact that small farms have a higher share of high land that is suitable for multiple cropping given the flood plain ecology of Bangladesh (Boyce 1987, Table 7.1). This simply means that when selling land for distress reasons, small farmers first sell their low-lying, less valuable land, and try to hold on to the more valuable land until the very end. Thus the aggregate data on size-productivity relationships have to be interpreted with great care. The higher yields on small farms may be due to desperate survival strategies of small peasants in backward areas, using backward technologies, who are surviving by severe labour intensification, rather than enjoying any intrinsic efficiency advantage. The aggregate statistics could then be picking up the fact that most districts in Bangladesh still use labour-intensive agriculture and primitive forms of irrigation, and in these cases we would expect the inverse size-productivity 
relationship to hold. However, the conclusion that small farms have an intrinsic efficiency advantage does not follow, since the relationship is overturned in more advanced areas, and with mechanization.

The problem with looking at aggregate data at a point in time is that it does not allow us to distinguish between farms that are making a transition to higher productivity through investment in new technologies and organizations and those that are persisting in the use of older technologies and methods of production. Aggregating across farms of all types is likely to reveal characteristics of the statistically dominant types without telling us very much about how, if at all, the size-productivity relationship may be changed by a transition from less productive to more productive modes of production. It follows that it cannot also help us to identify the possible constraints being faced by such a transition. Conventionally, traditional methods of production have been described as 'non-capitalist' or 'peasant', and the emerging modern forms of production and organization as 'capitalist'. But it is widely recognized that in developing country agriculture separating the universe of farms into 'capitalist' and 'non-capitalist' groups before carrying out a test of the size-productivity relationship is fraught with methodological problems. The 'capitalist' farms we would expect to see would be very unlikely to conform in all respects to the characteristics of the pure types identified by theory. They are more likely to have mixed characteristics, for instance using somewhat more advanced technologies, but using forms of labour management that would not be immediately recognized as being capitalist. Equally, pre-capitalist peasant farms might regularly use significant amounts of wage labour without thereby becoming capitalist farms.

In an interesting case study, Toufique (2001) gets around this problem by suggesting that the size-productivity relationship varies across regions within Bangladesh depending on the level of development of technology and on environmental opportunities. He compares a 'backward' with an 'advanced' region, defined in terms of agrarian ecology and other environmental, social and historical factors that made one area more suitable for more productive HYV technologies and the other less so. Both were about the same distance from the capital city Dhaka. He finds that in the relatively advanced area, where the environment was more conducive for intensive farming, and technology was more developed, the traditional size-productivity relationship was reversed. In other words, in the advanced region large farms were more productive. This is exactly what we expect to see given the experience of capitalist development in agriculture all over the world. The inverse size-productivity relationship seems to be a characteristic of relatively low-technology peasant farming where large farms are not making a transition to high-productivity proto-capitalist farming. Here poor peasants on small farms appear to be more productive but only because they are forced into severe labour intensification to survive. And indeed Toufique finds the inverse relationship to hold in the backward region.

These observations suggest that the inverse relationship is overturned when agricultural growth takes off with investment in new technologies. The idea that large farms face an absolute supervision constraint that prevents yields being 
increased on these farms is counter to all historical experience. Even if large farms initially faced a supervision constraint, there are two logical routes out of this constraint. The first possibility is for large farms to invest in labour-saving technology, for instance in mechanization, that allows yields to be increased without more labour being required per acre, or even with less labour per acre. If this can be achieved, large farms could potentially attain much higher yields than smaller farms. A second possibility is that technology remains labour-using, but large farms are nevertheless able to use labour more intensively by investing in institutional innovations that allow them to overcome their supervision constraints. These innovations would include new management structures and incentives that allowed labour to be intensively used on large farms.

In his study, Toufique finds that the advanced region in Bangladesh did not solve the labour management problem through labour displacement and mechanization alone, but also through new forms of labour management. This involved an adaptation of the old sardari system of labour management, with the sardar or team leader of a labour gang contracting to provide a specified service such as completing the harvest, for a payment fixed in advance. This system was widely used in the advanced region, suggesting that it offered higher supervision efficiency than if labour was hired and managed directly by the employer. This could be because employers could choose between competing teams, and team leaders had long-term relationships with their teams allowing them to use forms of disciplining not available to individual employers. While large farms using labour teams are not identifiably 'capitalist' in the classical sense, they had clearly innovated new institutional forms to deal with specific management problems. Whether this is a transitional form on the road to more recognizable 'capitalist' forms must for the time being remain an open question. The interesting observation made by Toufique is that even with these intermediate forms of labour management, the size-productivity relationship breaks down in the technologically advanced region. Not only is there no inverse size-productivity relationship, there is a significant and positive relationship between farm size and productivity and larger farms are more productive (Toufique 2001).

Thus, neither GKI's mechanism of monopsony nor the World Bank's supervision constraints were sufficient to hold back high yields in large farms in advanced areas. The evidence provided by Toufique, though it is from a limited range of observations, is credible because it is consistent with a broad range of cross-country historical observations (see also Dyer in this issue). Large farms can invest more and are thus likely to have higher net returns over time provided the appropriate technologies are available, and provided institutional innovations can be made to manage labour in ways that are appropriate for increasing profitability. Lower yields on large farms seem only to apply to backward regions, and here small farms truly appear to have a static advantage in terms of yields. However, even here, the welfare implications of the poor peasants intensifying labour application severely to survive on small farms may actually be dire. Even if we ignore these welfare implications, and even if we 
focus only on backward areas, the policy proposal of redistributing land to small farms may be of dubious value as this will at best lead to a one-off improvement in output, leaving the agrarian economy in perpetual poverty. Neither GKI nor the World Bank provide any theoretical or empirical arguments to demonstrate that small farms have higher growth rates of output, particularly once new technologies become available and growth becomes dependent on the capacity to sustain higher rates of investment, and on the social power to negotiate new institutional arrangements.

Given these observations about small and large farms, the concern of both GKI and the World Bank to transfer land to small farmers as a way of enhancing productivity clearly seems to be misplaced. As far as raising productivity is concerned, the relevant question to ask in a country like Bangladesh is why are the relatively advanced regions so few and far between? This raises macro-social, environmental and technological questions about the conditions required to become a relatively advanced region. In the specific ecology of Bangladesh, water management is one of the primary factors that determines which regions are suitable for HYV technologies and mechanization, and which are not (Boyce 1987; Mahbub Ullah 1996; Toufique 2001). These in turn depend not only on accidents of geography, but also on the politics that determines where embankments, dams, barrages and irrigation canals are built on the basis of central government investments. The transition to more productive modes of production is thus not a process whose drivers and constraints are entirely determined at the level of the farm or even of the village. Here lies one of the major shortcomings of most studies of the agrarian transition in countries like Bangladesh. While the role of the state in constructing agricultural infrastructure is widely recognized, the determinants of why the state does not do this more vigorously are inadequately theorized.

But even if GKI and the World Bank are wrong in their preconception that small farms are more efficient, have they at least identified the obstacles that may be preventing the consolidation of land in the hands of more productive farmers? This is a question of some concern since even if large farms are more productive, at least in the advanced areas, we find relatively slow progress in the concentration of land within the advanced regions. Even in these regions, large farmers who are relatively more productive remain small in international terms. Thus, we also need to ask why land does not become rapidly more concentrated even in these regions to further enhance productivity. GKI's mechanism is by definition not relevant in this case. Monopsony power might explain why large farmers may not want to sell land; it cannot explain why large farmers are failing to buy land from smaller farmers. But could it be that the World Bank is right that the problem may be high transaction costs in the land market? If so, reducing transaction costs could enhance agrarian productivity, not by allowing small farms to acquire more land, as the World Bank believes, but rather by allowing large farms to buy more land from smaller farms. However, we will argue that even the transaction cost explanation fails to identify the most significant obstacles facing land restructuring in developing countries like Bangladesh. 


\section{Mushtaq Husain Khan}

\section{POWER, POLITICS AND THE AGRARIAN ECONOMY}

We have seen that the GKI-World Bank presumption in favour of small farms is a generalization based on questionable observations in the case of Bangladesh. Cross-country work that we have referred to shows that the empirical weakness of the inverse size-productivity relationship is of general concern and is not just limited to Bangladesh. It is a separate, if related, question to ask if either GKI or the World Bank has satisfactorily identified the obstacles that may have prevented ownership shifting in the direction of greater efficiency. Regardless of whether large or small farms are more productive, if the obstacles to efficient transfers are correctly identified, this could be relevant for understanding why transitions in the direction of greater efficiency are blocked in general. For GKI, the obstacle to transition is the fear of a loss of monopsony power on the part of large landlords that prevents land sales to more efficient small farmers. We have argued that the evidence for such monopsony power is hard to find, certainly in the Bangladesh case. Moreover, the monopsony explanation is not relevant if the productivity-enhancing transfer that is blocked is one from small to large farmers. At a more general level, we have shown that as an explanation of blocked transformation, the monopsony argument collapses into a specific case of the high transaction cost explanation preferred by the World Bank. But equally, if reforms to reduce transaction costs have no chance of working, the Bank's transaction cost argument in turn collapses into the GKI position, since then the only way of achieving higher agrarian productivity would be to carry out redistributive land reform in favour of more productive farmers, be they small or large.

However, GKI's argument is more interesting than that of the World Bank in one respect. They implicitly recognize that a transaction cost explanation on its own is too broad and unsatisfactory without identifying an underlying 'political' problem that prevents its resolution. Why, after all, have transaction costs not been reduced already? If the costs of transacting are too high in the agricultural land market because the courts, legal record-keeping systems and enforcement mechanisms do not work, both large and small farmers are losing out because of lost trading opportunities. There should be strong pressures in such a context for legal institutions to be reformed. But in societies such as Bangladesh, no effective legal reforms for strengthening property rights have been articulated, let alone implemented, after many decades of high transaction costs. On the contrary, all the indications of growing violence, corruption and contestation over land suggest that transaction costs have been increasing over time, with greater and greater uncertainty and costs associated with the protection and transfer of agrarian property rights.

There are conceptually three possible types of explanations for persistently high, and even growing transaction costs. First, it could be that the parties concerned have simply not worked out their mutual benefit from reforming the institutional structure. This is not credible in a context such as that of Bangladesh. The legal enforcement system does not work, and the effects on everyday life are widely recognized by virtually everyone in the agricultural sector, and 
indeed in the economy as a whole. It is even less credible in recent years given the active campaigning by academics and NGOs within Bangladesh, and the much more forceful campaigning and pressure coming from international organizations like the World Bank.

Secondly, it could be that the parties concerned have worked out what needs to be done, but they have discovered that the economic cost of organizing institutional reform is too high compared with the potential benefits. The relevant costs are the costs of clarifying land records, improving the court system and its procedures, and so on, which would together reduce transaction costs over time. The benefits are the potential benefits of enhancing agrarian productivity through more rapid and less costly transfers of land to efficient users. If the costs of change were higher than the benefits, it would indeed be efficient to do nothing and just live with stagnation, since the potential improvement in growth would not be worth the costs of achieving it. But this too is not credible given the enormous benefits that could be captured over time from restructuring institutions responsible for high transaction costs, if there really were significant differences in the productivity and growth potential of different farms. The benefit of allowing rapid transfers of land from less efficient to more efficient farmers would be higher output and perhaps higher growth year after year, and over time this would almost certainly outweigh the one-off costs of institutional reform.

If neither ignorance nor the impossibly high costs of institutional reform provide satisfactory explanations for persistently high transaction costs, the third and only other possibility is that reform threatens powerful groups who can effectively resist change (M.H. Khan 1995). Even if institutional reforms may in aggregate cost less than the potential benefit, not everyone who loses out is likely to be fully compensated. As a result, some powerful potential losers may block socially desirable reforms that threaten to hurt them. This is a general possibility that is relevant in all cases of potential institutional change. We argue that this is the most promising route for identifying the real obstacles to agrarian transformations, and indeed for analysing social transitions in general. It is not surprising that historical evidence shows that dramatic institutional changes have almost always been preceded or accompanied by equally dramatic political conflicts and struggles that served to weaken the relative power of powerful interests opposed to change (M.H. Khan 1995). Equally, when attempts at institutional change fail, this is also often accompanied by political conflicts where powerful losers are able to block change. Even more common are cases where institutional change is not even attempted because powerful groups who wish to resist change happen to dominate the political process.

Thus, we need to ask if specific groups or classes may be blocking productivityenhancing changes in developing country agriculture. These groups or classes could be property owners or workers in agriculture, but they could also be outsiders whose incomes are affected by institutional change in agriculture. One of the features of developing country agriculture is the involvement of large numbers of people who are not directly involved in agricultural production in the contestation and protection of property rights. Some of these individuals are 


\section{Mushtaq Husain Khan}

located within the state institutions that regulate and protect property rights, but many others are political and organizational 'activists' who stand to lose substantially if property rights became better defined. These potential losers are typically very powerful in the political networks that govern developing countries, and they can block a productive transition that threatens to hurt them even before it starts. Thus we would argue that to understand the direction and pace of agrarian change, we have to look not only at the configuration of class forces in the agrarian sector, but also at political processes and conflicts within the state and across society as a whole (Byres 1996, 6-8; Brenner 1976, 1985).

From this perspective, GKI's analysis, despite being entirely neoclassical, can be welcomed for trying to identify a political conflict that might explain why transition is blocked. Unlike the World Bank and its supporters who seem to believe that agrarian transformation can be achieved through a series of technocratic institutional reforms such as sorting out inconsistencies in land records, improving the efficiency of the court system, and providing microcredit to small farmers, GKI clearly have a gut feeling that such an approach would be woefully inadequate. Where they go wrong is in their static understanding of how agrarian efficiency can be improved, and, more significantly, in their attempt to identify the source of political conflicts in agriculture using an ahistorical neoclassical monopsony model. Nevertheless, they do try to move beyond a generalized 'high transaction cost' model by implicitly trying to explain why transaction costs remain high. Their answer is that if the market were to operate efficiently, large landlords would lose out, and they are politically powerful enough to prevent the market from doing this. The theoretical and empirical problems with this model that we have discussed earlier mean that, while we are sympathetic to the motivations behind GKI's model, we are forced to reject their substantive analysis.

We need to proceed further to identify the political forces that might be opposing efficient and effective property right transfers to more productive farmers. An insight into the factors that may be preventing land purchases leading to the concentration of land in the hands of more efficient farmers is provided by Mahbub Ullah's detailed (1996) study of land transfers in Bangladesh. He provides an intensive investigation of land transfer processes in two villages over a 14-year period from 1972 to 1986. As with Toufique, one of his villages is an advanced village enjoying better water control infrastructure and higher yields, while the other is subject to flooding, and, as a result, suffers from lower yields. His aim is to compare farms that were stable, declining and growing in size in each village in order to identify the economic or social factors that differentiated them. Thus, instead of asking whether small or large farms were more efficient, Mahbub Ullah asks a related question: what determines which farms grow and which decline in size over time? Like Bhaduri et al. (1986) before him, Mahbub Ullah finds that the aggregate distribution of land remains remarkably stable over time in both villages, despite some important differences in their internal dynamics. This 'stability' in the overall distribution persists despite the presence of an active land market in both villages, a paradox that Mahbub Ullah describes as 'ubiquitous change in changelessness' (1996, 240). 
Even more surprising, when Mahbub Ullah tracks carefully the characteristics of farming households in the growing, stable and declining categories, he finds that they do not differ significantly in terms of either land or labour productivity (1996, 176-92, esp. Tables 9.1 and 9.2). Note that this does not mean that large and small farms have the same productivity. Mahbub Ullah is not interested in that debate and does not present his productivity figures classified by size of farm. What his evidence shows is that when we look at the average productivity of growing, stable and shrinking farms, there is no significant difference in their labour productivity or in the yield of land! A deeper examination shows why this is not such a surprising result. First, farms of every size group are in each of the change categories. For instance, there are small farms that are declining, growing or remaining stable, as well as large farms. This helps to explain why the 'growing' group is not on average different in productivity from the 'stable' or 'declining' groups. It also helps to explain why the aggregate land distribution does not change dramatically over time, since a number of farms in all size categories are growing and shrinking and all farms are packed within a very narrow range of sizes. Nevertheless, there are some noteworthy differences between the advanced and backward village. In the advanced village, large farms were more likely to be stable or growing. This meant there were some tendencies towards land concentration but very slight ones, compared with counter-tendencies towards land fragmentation due to population growth and land partitioning. In the backward village, large farms were almost as likely to lose land as other groups, partly because large farmers often sold out to migrate. However, these small differences did not translate into significant differences in processes of land concentration across the two villages given the common pressures in both of land partitioning due to population growth (1996, 234-5).

Secondly, in both villages, very small farmers showed the greatest tenacity in holding on to their last pieces of land. This 'stability' at the lowest level, which as Pandian (1987) amongst others has pointed out is due to desperate attempts by the poorest not to be proletarianized, means that the poorest farmers will often not sell out at any price. This 'irrational' behaviour on the part of small farms is the exact reverse of the GKI argument. The evidence suggests that, if anything, the transfer of land to more productive farms is slowed down by the unwillingness of small farms to sell land. The overall effect of this factor is likely to be small, but it does contribute to slowing down the process of differentiation.

Thirdly, Mahbub Ullah points out that the range of farm sizes is actually quite narrow, and even 'large' farms are in fact quite small in absolute terms. This means that the dynamics of land transfer cannot be largely driven by productivity differences. If farms were large and each generated a large surplus, the more productive farms would have a bigger surplus and would be able to buy out the less productive ones. But in Mahbub Ullah's villages, even large farms made very little actual surplus that they could then invest in buying more land. As a result, only 13 per cent of land purchases in the backward village and just 15 per cent of land purchases in the advanced village were financed by agricultural income. The vast majority of purchases in both villages were financed by 
non-agricultural incomes, including remittances from family members living outside the village and sometimes overseas, from trading incomes, and so on (1996, 235-7). Since non-agricultural incomes have no obvious correlation with the productivity of the associated agricultural activity the extended family may be engaged in, it is not surprising that land transfers do not follow any persistent trend towards concentration of land in higher-productivity size groups. These numbers powerfully underline the fact that while there are markets in agriculture, in Bangladesh, as in many other developing countries, agriculture does not follow what can be described as a capitalist logic. This observation is of fundamental significance. There is no reason to believe that a market will lead to the emergence of a more productive capitalist agricultural sector in a context of stark poverty and desperate survival strategies on the part of 'large' and 'small' farms that are in most cases better described as medium to poor peasants. These observations are quite contrary to the GKI model and its identification of the unwillingness of large landlords to employ labour or sell land as the source of agricultural backwardness. But while GKI's focus on a monopsonistic market failure is completely inappropriate for countries like Bangladesh, the generalized market failure approach of the World Bank is equally inapplicable. The processes Mahbub Ullah describes are unlikely to be significantly changed if land and other markets in agriculture began to work somewhat more efficiently, as the World Bank and others want. Even if institutional changes that reduced transaction costs were successfully implemented, peasants who were marginally more productive would still have an insufficient surplus to drive a process of rapid concentration, and less productive peasants would still hold on to their land as an insurance policy in a context of poverty. The most likely outcome would be that the process of churning of small amounts of land between backward peasant farms that were only marginally different from each other in terms of productivity would simply happen somewhat more efficiently.

Thus, the structure of landholdings described by Mahbub Ullah and others implies that an efficient market would be insufficient for organizing a productivity transformation in this type of developing country context. A necessary condition for a productivity transformation in agriculture would be the consolidation of landholdings into farms that were of higher productivity, and which could drive further productivity growth through the re-investment of farm surpluses. This type of transformation to higher productivity in agriculture has typically involved a capitalist transition that has created farms of a size adequate for generating and re-investing an agrarian surplus. But how is this to come about? If pre-capitalist farms have to consolidate and become capitalist farms through the market, they must first generate a sufficient surplus in their pre-capitalist state, big enough to enable them to invest in land and technology to become proper capitalist farms, with further productivity growth following. This is a chicken-and-egg problem, since clearly a critical minimum degree of productivity is required for the market to subsequently drive further productivity growth. The low productivity of pre-capitalist farms can thus itself be a problem in the path of a capitalist transformation. 
It is not surprising, therefore, that the capitalist transition has often been driven by non-market processes that have been referred to as 'primitive accumulation'. Primitive accumulation refers to the non-market transfer of assets from non-capitalist classes to pre-capitalist classes who may become capitalists over time. If successful, primitive accumulation results in the creation of an assetowning and productive capitalist class and a working class of 'free' workers who are obliged to work for them through an efficient labour market. At the same time, processes of primitive accumulation involve huge injustices and social waste, and there is no guarantee that an efficient capitalism will eventually emerge. But while primitive accumulation does not guarantee the emergence of an efficient capitalism, variants of primitive accumulation have usually been a necessary precursor of agrarian capitalism, particularly when the prior landholding structure was too fragmented to have led to land consolidation through the re-investment of agrarian surpluses (Habib 1995). Historically, mechanisms of primitive accumulation have included not only outright theft, seizures of land and expulsions of incumbent peasants, but also relatively more subtle interventions by states to change relative prices and to introduce laws that eventually had the same effect of accelerating the concentration of land in the hands of capitalist or proto-capitalist farms. The classic example of primitive accumulation was the English enclosure movement that created the large farms on which sheep farming and eventually English agrarian capitalism developed. The dispossession of Red Indians from their traditional lands in the United States, the capture of public lands in Thailand by emerging capitalists, and even the land reform in South Korea and Taiwan that transferred land to more productive proto-capitalist peasants are all examples of non-market transfers that accelerated the emergence of a higherproductivity agriculture. These examples show that non-market transfers of land are not necessarily always transfers from poorer to richer farmers, though in many cases they have been just that. More importantly, they show that the emergence of capitalism has rarely been a tranquil process through which everyone has gained, where the rule of law was upheld, and where the state simply had the role of maintaining a level playing field. In countries like Bangladesh, where a significant share of the total land belongs to an economically struggling and low productivity peasantry, the emergence of a bigger capitalist sector is very likely to involve non-market dispossessions of some very poor peasants. This may be neither politically viable nor morally justifiable, but neither is there any reason to believe that the efficient operation of the market is necessary or sufficient to transform this poverty-stricken peasant economy into a dynamic capitalist agriculture.

The possible role of primitive accumulation in agrarian transitions in developing countries brings us to a fourth factor that Mahbub Ullah only touches on but which is probably the most significant for explaining the overall dynamics of the Bangladeshi agrarian sector. To the extent that there is primitive accumulation going on in the agrarian sector in Bangladesh, why does this not lead to land concentration in the hands of any particular class of farmers? To understand the significance of this question, remember that there may be two quite separate 
constraints facing a capitalist transformation in the agricultural sector in a developing country. So far we have concentrated on market processes of transformation, and asked why transaction costs may be too high to enable a rapid re-allocation of land through the market to more productive farmers. However, market processes are not the only mechanism through which land is transferred in developing country agriculture, and they may not even be the more important set of processes through which the agrarian structure has changed in the case of successful transitions in history. If primitive accumulation of different types is happening, we have to ask why that is also not leading in Bangladesh to the emergence of a productive capitalist farm sector.

Since we have suggested that groups with political power may have resisted institutional changes in the direction of lowering transaction costs, an examination of non-market land transfers may throw further light on this question since groups with political power can be expected to be the principal beneficiaries of primitive accumulation. Who are the groups driving primitive accumulation in a country like Bangladesh, and why have they not succeeded in capturing enough land to have become capitalist farmers over time?

This is an important question because processes of primitive accumulation are widespread in the rural economy of countries like Bangladesh. It is certainly not the case that rural Bangladesh is a law-abiding place where land is only transferred through market processes. In fact, in Bangladesh and in other developing countries, as the World Bank and the transaction cost literature keeps telling us, property rights are most inadequately protected and substantial resources have to be spent not only to transfer property rights, but also to retain them on a dayto-day basis. This aspect of high transaction costs is a reflection of the fact that primitive accumulation is constantly taking place, and resources have to be spent to protect property rights and not just to transfer them. Even a casual glance at newspapers tells us that in countries like Bangladesh land grabbing and 'non-market' transfers are common, and many individuals fail to retain their land in a context of great uncertainty about property rights. Non-market transfers of this type involve the powerful and the well connected using the police, the courts, the land record offices and frequently private armies of thugs to fabricate documents, institute false cases, and directly use violence or the threat of violence to extort and wrench land from the politically weak. But why do we not see concentration happening through these processes? If land-grabbing and other forms of primitive accumulation had resulted in a concentration of land in the hands of larger farmers, we may eventually have witnessed the emergence of a more productive proto-capitalist class, or we would be able to say with much greater confidence that large farmers were indeed less productive if they failed to achieve viability despite acquiring land. Instead, as Mahbub Ullah and others have observed, the linkages of landholders with power brokers and the state's patronage network, far from accelerating the emergence of large proto-capitalist farms, is one of the factors explaining the indeterminacy in the dynamics of land transfers $(1996,238)$. Thus in countries like Bangladesh it seems that primitive accumulation (like the market) only contributes to a permanent process of 
'churning' of small parcels of land between relatively small farms. But why should this be so? Mahbub Ullah does not provide an answer to this critically important question, so we have to seek some clues in the wider literature on the political economy of Bangladesh.

On the one hand, we could conclude from the 'change in changelessness' characterizing primitive accumulation that in countries like Bangladesh primitive accumulation is not driven by political power at all. We would reach this conclusion if we expect political power to be concentrated in a particular size-class of farms, in which case primitive accumulation driven by power should have benefited that size-class. Since this is patently not happening, we may conclude that the instability of land rights does not reflect a power-driven process at all, but is rather a manifestation of administrative failure. This is the conclusion reached by H.Z. Rahman (1996) who provides evidence that, in rural land disputes, farms of all size-classes can gain or lose land, with no significant evidence that bigger farmers are benefiting at the expense of the smaller. Rahman concludes from this that the problem of rural insecurity and the instability of land rights is not a class issue, but rather an effect of administrative and institutional failure. This might explain why non-market transfers of property rights display a large degree of randomness. In a position that is ultimately quite close to that of the World Bank, though coming from a different analytical perspective, Rahman argues that the reform priority is to improve land administration, address the conflicting sets of land records and the pervasive corruption in record-keeping, and address in general the administrative weaknesses in the legal and policing systems protecting land rights. These administrative reforms are not only the priority, they promise to bring benefits to all rural classes. While administrative weaknesses are undoubtedly important issues to address, this explanation raises for us the same question that is raised by the World Bank's policy position on transaction costs. Why have these universally desirable reforms not already been implemented, and why are they not being implemented even now, despite the pressure from academics, the lending resources and policy advice coming from the World Bank, and the apparent gains to be made by all rural classes?

Our evaluation is rather different. The absence of any impetus to organize administrative reforms to counter this primitive accumulation (and to reduce transaction costs) cannot be explained simply as a persistent bureaucratic failure, even though the latter is clearly real enough. There is virtually no political initiative from any political organization to reform the institutional structure in a way that would reduce property right instability, stop primitive accumulation, or otherwise reduce transaction costs. Parts of the bureaucracy would undoubtedly resist such attempts because it would reduce their opportunities for corruption, but, in reality, there is little evidence of any conflict on this issue between the political representatives of landed interests and the bureaucracy. Indeed, all the evidence suggests the very opposite. There is very close collaboration between local political elites, their landed allies and the bureaucracy in processes of primitive accumulation. Far from opposing the instability of land rights, local landed elites try their best to exploit this instability for their own benefit, and are 
often pushing and corrupting the bureaucracy, the police and the courts in ways that further increase instability. At the village level, virtually every rich peasant of any standing is allied with one or other local political faction, and they are intensely engaged with the local bureaucracy and the police to further their strategies of primitive accumulation. Any observer of these processes must conclude that landed classes are just as much responsible for the corruption and arbitrary interventions of bureaucrats and courts as they are victims of these forces. Mahbub Ullah's 'change in changelessness' does not describe the absence of politics, and the subservience of landed interests to the random vagaries of a badly working administrative structure. Rather, it describes a situation of intense political conflict that is most often driven by highly organized and politically active landed peasants. The paradox is rather that despite the exercise of their political power, few rich peasant farms grow beyond a point. And the reason for that is that their competitors are continuously and successfully challenging their growth.

The dynamics of primitive accumulation in rural Bangladesh are primarily driven by, and at the same time constrained by, political forces. The task of political economy is to explain why this politically driven process results in 'churning', rather than the concentration of land, and to investigate the implications of such an analysis for social and economic policy. Studies of Bangladesh's rural political economy help to throw some light on this issue. S.A. Khan's (1989) study of three villages in Bangladesh over the period 1975-80 is an example. His study describes the powerful patron-client networks through which landed peasants are engaged in an interminable conflict with their neighbours over land and resources. But far from accelerating any tendency towards concentration, Khan describes how primitive accumulation driven by the competition between almost equally balanced patron-client networks can slow down the process of land concentration. The critical point is that political power in the Bangladeshi rural context comes not just from prior land ownership and wealth but also, and perhaps primarily, from belonging to one or other of a number of patron-client factions. This is not surprising when we remember that the landholdings of all landed peasants are distributed within a narrow range. Powerful peasants in such a context are those who are politically well connected, and these peasants can then use the political power of their factions to grab the land of others. But the competition and balance of power between factions also means that those who are attacked today have a good chance of reclaiming or resisting these encroachments tomorrow. This political economy provides an explanation of stability in land distribution over time that is consistent with intense politically driven primitive accumulation.

The organization of landed peasants in factions, and the balance of power between competing factions, can in turn be explained by the disposition of class forces in this society. We know that, at the national level, the predominant types of political organizations in Bangladesh (and in many other developing countries) are multi-class factional organizations with individuals from the 'intermediate' classes playing critical leadership roles (M.H. Khan 2000a; Riaz 1994; 
S.A. Khan 1989). Intermediate classes are a residual group of classes who are neither capitalists nor landlords nor workers nor poor peasants. They rely to some extent on selling or using their own labour, but they also have some property and/or the organizational and political power to claim a share of the social surplus through the state. The intermediate classes include the urban pettybourgeoisie, middling to rich peasants, middle-class professionals, the educated unemployed, and white-collar workers. In most developing countries, they are of critical political importance because of their dominant organizational power compared with other classes, and political entrepreneurs coming from intermediate class groups have dominated leadership positions in political organizations at all levels of society. Nevertheless, these groups do not represent any identifiable 'intermediate class' interests, nor do major political parties typically represent the interests of any clearly defined class. This has led many observers to conclude that class is not relevant for understanding the exercise of political power in developing countries like Bangladesh. But, in fact, these observations can be better explained by the disposition of class forces in a transition economy. The fact that the intermediate classes do not organize to defend the interests of the original class they happen to have come from is not surprising given the much bigger prize that political entrepreneurs can hope to capture in such economies by engaging in primitive accumulation. This is also true of other classes, who do not lack class interests, but who find that redistributive politics organized by factions can offer them higher potential rewards in most cases. As a result, we observe that politics in developing countries consists largely of a competition between pyramidally organized factions that are dominated by members of the intermediate classes at leadership levels, though they may include many ordinary workers and peasants at the lowest levels, and capitalists and large landlords at the highest levels. The most important observation for our purposes is that political power in such countries is largely based on organizational power and not primarily on economic power. This reflects the fact that societies like Bangladesh are 'transition economies' where capitalism is not yet the dominant sector of the economy, while at the same time, pre-capitalist forms of production such as the peasant economy have become unviable or are suffering from serious economic problems. Political power in such societies is therefore typically not monopolized either by the old propertied classes (because they are no longer economically viable) or by capitalists (because they do not yet dominate the economy). Rather, political power is based on the organizational abilities of competing factions led by intermediate class political entrepreneurs, with factions intensely competing over the capture of economic resources. Variants of capitalist economies may emerge from these processes, but their emergence is by no means functionally necessary or pre-determined.

To understand processes of accumulation at the village level, we have to locate village politics within this context of economic and social transformations taking place at the national level. Given the concentration of economic resources at the centre in the form of the national budget, aid resources and government contracts, the competition between factions over public resources is most intense 


\section{Mushtaq Husain Khan}

at the national level. Lower level factions, including those organized at the village level, are nevertheless important as constituent power blocs that competing national factions have to incorporate selectively to enhance their collective bargaining power. Village politics is in turn characterized by the competition between factions that are usually linked to one or other national faction. At the lowest level, the basic or 'primary' patron-client factions are organized around a single or small group of intermediate class leaders who are able to mobilize organizational forces in ways that give the faction its organizational power. The foot-soldiers who are organized to provide this organizational power usually come from poorer classes, and they are mobilized in exchange for relatively small amounts of money or the promise of a small share in the resources to be captured by the faction. The organizational muscle that is thus mobilized can in turn be used for a variety of purposes, from mobilizing voters during elections to using force and violence against opposing factions. These basic patron-client factions are ubiquitous and range from neighbourhood groups led by petty mafia bosses known in Bangladesh as mastans to village factions led by only somewhat more respectable matabbars, dalals and upazilla chairmen. Depending on the resources that are being contested, the competition can be directly between basic factions or between coalitions of factions. Typically, in contests over major resources, higher-level political entrepreneurs construct coalitions consisting of many lower level factions. When we look at national level contests, we observe contests between political parties that are essentially pyramidal coalitions of thousands of primary patron-client factions. Lower level coalitions participate in these contests simply on the grounds of the rewards offered to them by higherlevel organizers, and frequent changes in 'party' affiliation are therefore common. At each level, bargaining power depends on the 'organizational power' that can be mobilized by the faction or the coalition of factions, whether it is for elections or for different types of violence or 'enforcement'.

The political organization of factions, the dominant position within them of the intermediate classes, and the dominance of organizational over economic power in contexts of economic transition are all important factors to bear in mind when explaining the dynamics of primitive accumulation in 'transition economies' like Bangladesh. The supply of foot-soldiers and of intermediate class organizers to organize them in competing factions far exceeds the resources that can be captured given the overall context of poverty and resource scarcity. This explains why political organizations are hopelessly fragmented in countries like Bangladesh, and no faction is safe for long when it does succeed in capturing state power at any level. If economic power had been the main basis of political power in these countries, primitive accumulation would systematically have favoured richer peasants in their attempts to appropriate land from poorer ones. But this does not happen in a systematic way because in fact the political power of peasants competing for land is based on their affiliation to powerful factions, and this is at least as important as their intrinsic wealth, if not more so. Large, middle or small peasants can belong to a temporarily successful faction, or to one whose fortunes have just been reversed. The cyclical success or failure of 
individual factions in turn depends on an ongoing and chaotic (but not random) re-alignment of the mosaic of primary factions, each driven by calculations of maximizing its bargaining power by aligning with shifting coalitions of factions at the national and other levels. This explains the paradox that primitive accumulation can be intense without necessarily resulting in a growing concentration of landholdings.

It is, of course, possible that such a process of primitive accumulation will eventually result in the creation of enough big capitalists with sufficient resources based on their profits to control major national political coalitions for their own benefit. If such a critical minimum mass of capitalists was ever to be achieved, the political process would begin to support capitalist-led primitive accumulation and the size of the capitalist sector would begin to grow rapidly. Something like this happened in the 'money politics' of Thailand in the eighties (Phongpaichit and Baker 1997; M.H. Khan 2000b). In contrast, in South Asia, emerging capitalists have remained too small relative to the size and organizational power of the relevant national factions, and factional politics has not yet been taken over by emerging capitalists to anything like the same extent (M.H. Khan 2000b).

Once we begin to unravel the political organization of primitive accumulation, we see that this political economy can also begin to answer a number of closely related questions. Where does the resistance to institutional reforms that aim to reduce transaction costs come from, and why does the state not invest more aggressively to develop rural infrastructure? If primitive accumulation at the village level is driven by factional political power, and these primary factions are constituents of national political coalitions that need their assistance in national contests, it is easy to see why the implementation of 'transaction costreducing' reforms has enjoyed so little political support from any political group. The losers from these reforms will not just be a few thousand bureaucrats whose opposition could have been relatively easily managed, but tens of thousands of lower-level factions at the village level that in fact constitute the coalition that is in power at the national level. Since the lower-level factions affiliated to the party in power are engaged in primitive accumulation, and their supporters are winning (for the time being), it is not surprising that there is typically no political support for any attempt to call proceedings to a halt. The fact that in aggregate no size class is winning does not mean that stopping primitive accumulation will have the support of all classes. Village faction leaders might know that eventually they may themselves be in opposition, and their gains may be transient. Nevertheless, it makes no sense for any particular faction to stop its activities or indeed to stop trying to overturn past wrongs, without a guarantee that all other factions will do the same for evermore, and all past wrongs will be righted. This is nothing less than a massive prisoner's dilemma with millions of players. Without understanding the political nature of the problem and addressing it in some way, strategies of institutional reform that focus on technocratic issues are simply not going to work.

Far from being irrelevant, the analysis of class, politics and power in specific countries and contexts helps to show why neoclassical approaches to agrarian 
constraints are woefully inadequate. If our analysis is right, no amount of loans from the World Bank to carry out institutional reforms to improve the land record systems, or to improve the quality of district-level courts is likely to have any discernible effect on the big picture. The obstacles to changes in the direction of greater productivity are not just administrative and bureaucratic impediments that can be removed by technocratic reforms. The obstacles are political and organizational, and lie in the pattern of the primitive accumulation being driven by powerful political factions. Reducing transaction costs involves not just a few technocratic reforms, but actually stopping the primitive accumulation on which national political power is based in a transition economy such as Bangladesh. What is more, even if transaction costs could be reduced by miraculously stopping primitive accumulation, this would not necessarily result in rapid productivity growth for the reasons we have discussed in detail. In identifying the importance of power and politics, GKI's intuition is essentially correct. But their failure lies in trying to extract the nature of this political obstacle from a general and ahistorical neoclassical model. The identification by GKI of large farmers as the constraint to agrarian productivity growth, and their advocacy of redistributive land reform in favour of small farmers, is entirely the wrong answer to the problem, and has no basis in the observed facts of land productivity or the dynamics of agrarian change in Bangladesh or in other countries.

Political strategies that might work to address these issues are not the subject of this paper. All that we need to point out here is that some political strategy is critical to ensure that the type of primitive accumulation going on can be realigned to proceed in a more productive direction. The historical evidence suggests that the non-market transfers that are likely to generate high productivity in agriculture would be very different from the 'nice' redistributions envisaged by GKI, particularly given the fragmentation, low surplus-generating capacities and low technology of even medium farms in a context such as that of Bangladesh. In theory, many different political strategies could conceivably restructure primitive accumulation to achieve the end of organizing a capitalist consolidation, depending on political and economic conjunctures. For instance, it is possible to imagine the construction of a centralized and developmental political party that could constrain factional competition and re-allocate land and other resources from above to achieve the rapid development of a capitalist agriculture. It is also possible to imagine, however, more decentralized political strategies of supporting the organizational and economic capacities of proto-capitalist primitive accumulators to take over one or more national factions and drive primitive accumulation from below. Alternatively, collectivist and non-capitalist political strategies may envisage the construction of large farms that could be collectively owned. The strategies that may be most relevant for a particular country will depend on which classes are leading political change, and specific economic and political conjunctures may determine the viability of each of these strategies.

Factional struggles to capture the state and use it for short-term resource extraction can also shed light on the related issue of why the state does so badly in mobilizing resources for infrastructure construction or indeed in constructing 
appropriate infrastructure with the resources that are available. The construction of good infrastructure requires national-level priorities and an ability of the national state to implement these priorities. Instead, what we see in countries like Bangladesh is very often an uncoordinated patchwork of infrastructure projects whose location and type are determined by the accident of which party happens to be in power at the centre. Much more important than the coherence and integration of different infrastructure projects is the satisfaction of the primary factions that have been critical for the national coalition to come to power. Each of these factions will insist on having an infrastructure project in its home territory, and if this means building a disjointed structure of roads and bridges that are not connected to anything else, or irrigation canals that cause problems downstream, so be it. Again, this is not the main focus of this paper, but we want to argue that the intense primitive accumulation that paradoxically leads to a stalemate in the distribution of land, the deep political opposition to institutional reforms of courts and land records, and the fragmented approach to agrarian infrastructure are all manifestations of a common and deeper problem. This is a problem of political competition, fragmentation and possibly of stalemate in a context of economic transition where capitalism has not yet become dominant, but where the distribution of power and the factional competition between primitive accumulators paradoxically slows down the emergence of capitalism. To understand different variants of this problem across developing countries, and the possible political and social responses to these problems, we have to look at the specific structures of class and power in different transition economies in the developing world. We should certainly not be trying to derive general results from an abstract and ahistorical neoclassical economic model.

\section{REFERENCES}

Ahmed, I. 1981. 'Farm Size and Labour Use: Some Alternative Explanations'. Oxford Bulletin of Economics and Statistics, 7 (3): 73-88.

Bhaduri, A., H.Z. Rahman and A.L. Arn, 1986. 'Persistence and Polarization: A Study in the Dynamics of Agrarian Contradiction'. Journal of Peasant Studies, 13 (3): 82-9.

Boyce, J.K., 1987. Agrarian Impasse in Bengal: Institutional Constraints to Technological Change. Oxford: Oxford University Press.

Brenner, R., 1976. 'Agrarian Class Structure and Economic Development in PreIndustrial Europe'. Past and Present, 70: 30-75.

Brenner, R., 1985. 'The Agrarian Roots of European Capitalism'. In The Brenner Debate: Agrarian Class Structure and Economic Development in Pre-Industrial Europe, eds T.H. Aston and C.H.E. Philpin. Cambridge: Cambridge University Press, 10-63.

Byres, T., 1996. Capitalism from Above and Capitalism from Below: An Essay in Comparative Political Economy. London: Macmillan.

Coase, R., 1960. 'The Problem of Social Cost'. Journal of Law and Economics, 3 (1): 1-44.

Demsetz, H. 1980. Economic, Political and Legal Dimensions of Competition. Amsterdam: North Holland.

Faruqee, R. and K. Carey, 1997. 'Land Markets in South Asia: What Have We Learned?'. World Bank Research Paper. 
Feldman, S. and F.E. McCarthy, 1987. 'Persistence of the Smallholders, Withering Away of the Small Farmer: Comment on Bhaduri, Rahman and Arn'. Journal of Peasant Studies, 14 (4): 543-8.

Griffin, K., A.R. Khan and A. Ickowitz, 2002. 'Poverty and the Distribution of Land'. Journal of Agrarian Change, 2 (3): 279-330.

Habib, I., 1995. 'Processes of Accumulation in Pre-Colonial and Colonial India'. In Essays in Indian History: Towards a Marxist Perception, ed. I. Habib, 259-95. New Delhi: Tulika.

Khan, M.H. 1995. 'State Failure in Weak States: A Critique of New Institutionalist Explanations'. In New Institutional Economics and Third World Development, eds J. Harriss, J. Hunter and C. Lewis, 71-86. London: Routledge.

Khan, M.H. 2000a. 'Class, Clientelism and Communal Politics in Bangladesh'. In The Making of History: Essays Presented to Irfan Habib, eds K.N. Panikkar, T.J. Byres and U. Patnaik, 572-606. New Delhi: Tulika.

Khan, M.H. 2000b. 'Rent-Seeking as Process'. In Rents, Rent-Seeking and Economic Development: Theory and Evidence in Asia, eds M.H. Khan and K.S. Jomo, 70-144. Cambridge: Cambridge University Press.

Khan, M.M. 1987. 'A Note on Persistence and Polarization'. Journal of Peasant Studies, 14 (4): $538-42$.

Khan, S.A. 1989. The State and Village Society: The Political Economy of Agricultural Development in Bangladesh. Dhaka: University Press Ltd.

Mahbub Ullah, 1996. Land, Livelihood and Change in Rural Bangladesh. Dhaka: University Press Ltd.

North, D., 1990. Institutions, Institutional Change and Economic Performance. Cambridge: Cambridge University Press.

Pandian, M.S.S. 1987. 'On the So-Called Stability of Small Landowners in Bangladesh'. Journal of Peasant Studies, 14 (4): 534-7.

Phongpaichit, P. and C. Baker, 1997. Thailand: Economy and Politics. Oxford: Oxford University Press and Bangkok: Asia Books.

Rahman, A., 1986. Peasants and Classes - A Study in Differentiation in Bangladesh. Delhi: Oxford University Press.

Rahman, A., 1988. 'Small Farmers Are Being Proletarianized - A Note on Persistence and Polarization by Bhaduri et al.' Journal of Peasant Studies 15 (2): 283-7.

Rahman, H.Z., 1996. Land Administration and Rural Disputes: Findings from an Interface Study. Working Paper. Dhaka: Bangladesh Institute of Development Studies.

Riaz, A., 1994. State, Class and Military Rule: Political Economy of Martial Law in Bangladesh. Dhaka: Nadi New Press.

Toufique, K.A., 2001. Structural Constraint to Agricultural Growth: An Explanation of the Farm Size and Productivity Relationship in Bangladesh. Working Paper. Dhaka: Bangladesh Institute of Development Studies.

Van Schendel, W., 1982. Peasant Mobility - The Odds of Life in Rural Bangladesh. New Delhi: Monohar.

World Bank, 2000. Bangladesh: Study of Land Issues. Dhaka: World Bank Dhaka Office and SASRD. 